Received $13^{\text {th }}$ October 2017, Accepted $27^{\text {th }}$ November 2017

Link to DOI:

10.25220/WNJ/V01.i2.0011

Journal Website: www.worldnutrijournal.org

\title{
Commercial Powder and Ready-to-use Enteral Nutrition had better Accuracy in Energy and Macronutrients Content Compared to Homebrew.
}

\author{
Luciana B. Sutanto, ${ }^{1}$ Saptawati Bardosono, ${ }^{2}$ TStella E. Bela,${ }^{2}$ \\ 1. Gladiool Woman's and Child's Hospital, Magelang, Indonesia \\ 2. Departement of Nutrition, Faculty of Medicine Universitas Indonesia-Cipto Mangunkusumo \\ General Hospital
}

\begin{abstract}
Introduction: In Indonesia, homebrew, commercial powder and ready-to-use enteral formula have been used in hospital and at home. However, the decision to choose enteral formula is influenced by various things and often does not based on evidence-based practice. This study aims to compare macronutrient accuracy and microbial contamination status of homebrew, commercial powder and ready-to-use enteral formula. Furthermore, this result was expected to become a reference in deciding the enteral formula to use.

Methods: The design was a cross sectional comparative study. We collected 63 enteral nutrition samples from 7 different ICUs, wards and homes, in Jakarta from April to June 2012. Macronutrient accuracy was assessed by comparing energy, carbohydrate, protein and fat to their nutritional fact labels. The macronutrient accuracy was considered to be good if the deviation was $<10 \%$ and bad if $>10 \%$. Microbial contamination was considered to be acceptable if the contamination in enteral formula by coliform was $<3 \mathrm{MPN} / \mathrm{mL}$, total plate count (TPC) $<10$ $\mathrm{CFU} / \mathrm{mL}$, and Staphylococcus aureus $<10 \mathrm{CFU} / \mathrm{mL}$.

Results: Homebrew had bad accuracy in calorie, carbohydrate and fat; commercial powder enteral formula had slightly bad accuracy in fat; ready-to-use enteral formula had bad accuracy in carbohydrate and fat. There was no sample contaminated by Staphylococcus aureus. Contamination by coliform and TPC was most acceptable in ready-to-use enteral formula than others, and the least in homebrew.

Conclusion: Commercial and ready-to-use enteral nutrition are more acceptable than homebrew in macronutrients accuracy and microbial contamination status.
\end{abstract}

Keywords enteral formula, macronutrients accuracy, microbial contamination

\section{Introduction}

Hospital malnutrition in Indonesia is becoming a serious problem, however, there is no data

\author{
Corresponding author: \\ Luciana B. Sutanto \\ RSIA Gladiool Magelang, Indonesia \\ Email address : lcsutanto@yahoo.com
}

regarding this issue. In industrialized countries, several studies have identified this condition in 25$50 \%$ of the hospitalized population. ${ }^{1}$ Malnourished patients will certainly have higher rate of morbidity and mortality as well as longer hospital stay and higher cost.

There are several factors related to the etiology of hospital malnutrition, among others are the underlying illness for which the patient is hospitalized, and quality of hospital medical care which includes nutrition support care. ${ }^{1}$ 
Insufficiency in energy and macronutrient composition is a critical problem which, among others, is related to diet portioning and distribution, to fulfill the nutritional needs of the patients. ${ }^{2}$ Although there are few studies comparing the energy and macronutrient content of diet formulation however, different from micronutrients, it is assumed that food preparation does not lead to significant changes in macronutrients amount. ${ }^{2}$

Aside from the quality of nutrient content, the safety of enteral formula given to the hospital patients is also very important and can pose a significant risk to the patients. In general, the contamination of the formula with microorganism can occur at any point starting from the production, to preparation, storage, or administration process. ${ }^{3}$ During the preparation in the hospital or healthcare setting, the process of mixing, reconstitution, or dilution of modular products and formula with water, and/or pouring the formula into an administration container are critical points for contamination. The contaminated feeding increases the risk for nosocomial infections such as diarrhea, pneumonia and septicaemia. A study in the Philippines found that $75-96 \%$ of blenderized tube feeding samples were contaminated, while in Saudi Arabia the percentage was reported higher. ${ }^{4}$

Sterile ready-to-use (RTU) and commercial powders are available in Indonesia, however homebrew is still used. This preliminary study aims to compare the use of different enteral nutrition formula i.e. ready to use enteral formula, commercial powder and homebrew, in terms of energy and macronutrient composition accuracy, as well as the contamination.

\section{Methods}

Sample inclusion criteria including: 1) Homebrew, commercial powder and ready to use enteral nutrition sample which were taken from ICU, wards and homes in Jakarta; 2) Sample was kept in the standard collection cups, and 3) Sample was brought to the laboratory by using the cold box. The samples were excluded if the transportation of the samples to the laboratory were more than four hours.
Data collected were analyzed to get accuracy of the energy and macronutrition content of each product, and the microbial contamination status based on the coliform, total plate count (TPC) and Staphylococcus aureus counts. The energy and macronutrient content value was considered to be good, if it has less than $10 \%$ deviation of energy, carbohydrate, protein and fat between the laboratory findings compared to its nutritional fact label. On the other hand, the nutritional content value was considered to be poor, if it has $10 \%$ and more deviation of energy, carbohydrate, protein and fat in the laboratory findings compared to its nutritional fact label. For microbial contamination status, it was considered acceptable if the coliform counts was less than 3 $\mathrm{MPN} / \mathrm{mL}$, the TPC was less than $10 \mathrm{CFU} / \mathrm{mL}$, and the Staphylococcus aureus was less than 10 $\mathrm{CFU} / \mathrm{mL} .^{5}$

Data were then managed by using the Statistical Program for Social Sciences (SPSS) version 11.5. To compare the energy and macronutrient content accuracy of each of the product, paired-t and/or Wilcoxon test was used. McNemar-test was used to compare the energy and macronutrient accuracy status and the microbial contamination status between the products. The $\mathrm{p}$ value of less than 0.05 was used as the significance level.

\section{Results}

This study collected 21 samples from each of three different preparation locations, i.e. ICU and wards of the selected seven hospitals and home care patients in Jakarta per-product tested. The energy and macronutrient content level accuracy of different enteral preparation, as shown in Table 1, revealed that in average the homebrew product has poor accuracy (having more than 10\% deviation) except for protein content. On the other hand, the commercial powder formula, in average, only has poor accuracy for the fat content, and ready-to-use formula has poor accuracy for carbohydrate and fat contents. Furthermore, Table 2 shows the proportion of energy and macronutrient accuracy between the three different enteral formulas. 
Table 1 Macronutrient level accuracy of different enteral preparation formula

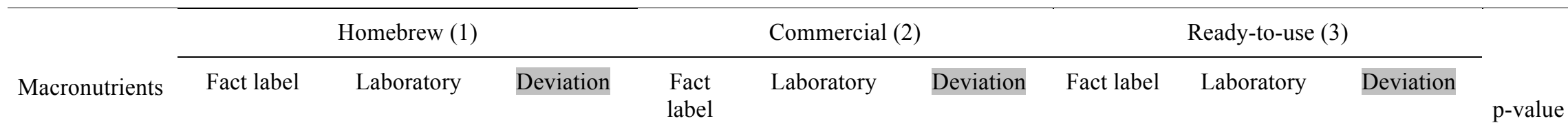

\begin{tabular}{|c|c|c|c|c|c|c|c|c|c|c|}
\hline \multirow[t]{2}{*}{ Calorie } & Kcal* & Kcal* & $\% *$ & $\mathrm{Kcal}^{\wedge}$ & $\mathrm{Kcal}^{\wedge}$ & $\%^{\wedge}$ & $\mathrm{Kcal}^{*}$ & Kcal* & $\% *$ & \\
\hline & $\begin{array}{c}100 \\
(87-155.3)\end{array}$ & $\begin{array}{c}60.2 \\
(41.3-154.1)\end{array}$ & $\begin{array}{c}-46.2 \\
(-59.6-53.1)\end{array}$ & $\begin{array}{c}103 \\
(10.1)\end{array}$ & $95.6(10.3)$ & $\begin{array}{l}-7.4 \\
(11)\end{array}$ & $\begin{array}{c}150 \\
(118.5- \\
150)\end{array}$ & $\begin{array}{c}135.8 \\
(96.5-148.5)\end{array}$ & $\begin{array}{c}-2.6 \\
(-10.7-10.2)\end{array}$ & $\begin{array}{l}\text { 1) } 0.003 \mathrm{a} \\
\text { 2) } 0.006 \mathrm{~b} \\
\text { 3) } 0.001 \mathrm{a}\end{array}$ \\
\hline
\end{tabular}

\begin{tabular}{|c|c|c|c|c|c|c|c|c|c|c|}
\hline \multirow[t]{2}{*}{ Carbohydrate } & $\mathrm{g}^{\wedge}$ & $g^{*}$ & $\% *$ & $\mathrm{~g}^{\wedge}$ & $\mathrm{g}^{\wedge}$ & $\%^{\wedge}$ & $\mathrm{g}^{*}$ & $\mathrm{~g}^{*}$ & $\% *$ & \\
\hline & $15.2(2.8)$ & $\begin{array}{c}6.9 \\
(3.6-21.2)\end{array}$ & $\begin{array}{c}-26.1 \\
(-43.6-33.6)\end{array}$ & $\begin{array}{l}14.5 \\
(3.4)\end{array}$ & $\begin{array}{l}15.5 \\
(3.4)\end{array}$ & $\begin{array}{l}3.8 \\
(9.7)\end{array}$ & $\begin{array}{c}17.3 \\
(13.8- \\
18.8)\end{array}$ & $\begin{array}{c}21.1 \\
(14.3-24.3)\end{array}$ & $\begin{array}{c}14.9 \\
(2.1-27.9)\end{array}$ & $\begin{array}{l}\text { 1) } 0.001 \mathrm{a} \\
\text { 2) } 0.092 \mathrm{~b} \\
\text { 3) }<0.001 \mathrm{a}\end{array}$ \\
\hline \multirow[t]{2}{*}{ Protein } & $g^{*}$ & $\mathrm{~g}^{\wedge}$ & $\% *$ & $\mathrm{~g}^{\wedge}$ & $\mathrm{g}^{\wedge}$ & $\% *$ & $g^{*}$ & $g^{*}$ & $\% *$ & \\
\hline & $3.6(2.3-6.7)$ & $2.9(0.9)$ & $\begin{array}{c}-2.6 \\
(-10-72.2)\end{array}$ & $3.7(0.8)$ & $\begin{array}{c}3.5 \\
(0.8)\end{array}$ & $\begin{array}{c}-1.1 \\
(-4.4-7.8)\end{array}$ & $\begin{array}{c}3.1 \\
(3.1-3.8)\end{array}$ & $\begin{array}{c}3.0 \\
(2.9-3.5)\end{array}$ & $\begin{array}{c}-0.6 \\
(-1.6--0.2)\end{array}$ & $\begin{array}{l}\text { 1) } 0.016 \mathrm{a} \\
\text { 2) } 0.112 \mathrm{~b} \\
\text { 3) }<0.001 \mathrm{a}\end{array}$ \\
\hline \multirow[t]{2}{*}{ Fats } & $\mathrm{g}^{\wedge}$ & $\mathrm{g}^{\wedge}$ & $\%^{\wedge}$ & $\mathrm{g}^{\wedge}$ & $\mathrm{g}^{\wedge}$ & $\% \wedge$ & $g^{*}$ & $g^{*}$ & $\% *$ & \\
\hline & $3.0(1.1)$ & $1.6(0.9)$ & $-12(10.2)$ & $3.3(1.3)$ & $2.2(1.2)$ & $-10.2(7.1)$ & $\begin{array}{c}6.3 \\
(3.4-6.8)\end{array}$ & $4.4(2.8-4.5)$ & $\begin{array}{c}-16.8 \\
(-52--5.2)\end{array}$ & $\begin{array}{l}\text { 1) }<0.001 \mathrm{~b} \\
\text { 2) }<0.001 \mathrm{~b} \\
\text { 3) }<0.001 \mathrm{a}\end{array}$ \\
\hline
\end{tabular}

*, median (minimum-maximum); ^ mean (sd); a), Wilcoxon; b, paired-t

76 | World.Nutr.J 
Table 2 Proportion of macronutrients accuracy of different enteral preparation formula for calorie-content accuracy

For Calorie-content accuracy

\begin{tabular}{|c|c|c|c|c|}
\hline \multirow[t]{2}{*}{ Type of formula: } & & \multicolumn{2}{|c|}{ Ready-to-Use } & \multirow[b]{2}{*}{$\mathrm{p}$-value (McNemar) } \\
\hline & & Good & $\mathrm{Bad}$ & \\
\hline Homebrew & Good & 0 & 0 & na \\
\hline & $\mathrm{Bad}$ & 21 & 0 & \\
\hline Commercial & Good & 13 & 0 & na \\
\hline & $\mathrm{Bad}$ & 8 & 0 & \\
\hline \multicolumn{5}{|c|}{ For Carbohydrate-content Accuracy: } \\
\hline \multirow[t]{3}{*}{ Homebrew } & Good & 0 & 0 & na \\
\hline & $\mathrm{Bad}$ & 1 & 20 & \\
\hline & & & & 0.031 \\
\hline \multirow[t]{2}{*}{ Commercial } & Good & 1 & 6 & \\
\hline & $\mathrm{Bad}$ & 0 & 14 & \\
\hline
\end{tabular}


Table 2 (continued)

For Protein-content Accuracy:

\begin{tabular}{|c|c|c|c|c|}
\hline \multirow[t]{2}{*}{ Type of formula: } & & \multicolumn{2}{|c|}{ Ready-to-Use } & \multirow[b]{2}{*}{$\mathrm{p}$-value (McNemar) } \\
\hline & & Good & $\mathrm{Bad}$ & \\
\hline \multirow[t]{2}{*}{ Homebrew } & Good & 3 & $\mathbf{0}$ & $<0.001$ \\
\hline & Bad & 17 & 1 & \\
\hline \multirow[t]{2}{*}{ Commercial } & Good & 9 & 1 & 0.006 \\
\hline & $\mathrm{Bad}$ & 11 & 0 & \\
\hline
\end{tabular}

For Fats-content Accuracy:

\begin{tabular}{llll}
\hline Homebrew & Good & 0 & 0 \\
& Bad & 0 & na \\
& & & \\
Commercial & Good & 0 & 21 \\
& Bad & 0 & 19
\end{tabular}


By using ready-to-use (RTU) formula as "gold standard", the proportion of poor energy accuracy is found in all of the homebrew samples, as compared to only 4 to 21 in RTU samples. On the other hand, there is no significant difference in the proportion of poor energy accuracy between RTU and commercial powder formula $(p=0.344)$. Furthermore, almost all RTU and all homebrew samples had poor carbohydrate accuracy, and there is a significant lower proportion of poor carbohydrate accuracy in the commercial powder compared to the RTU formula $(p=0.031)$. This evidence is similar with the proportion of poor protein accuracy, no significant difference between homebrew and RTU formula, but there is a significant lower proportion of poor protein accuracy in the commercial powder compared to the RTU formula $(p=0.039)$. Finally, there is no significant difference in the proportion of poor fat accuracy in all samples.

Further analysis on the micro-organisms contamination, as shown in Table 3, revealed that there is no single sample contaminated by Stahpylococcus aureus, however, there are significant lower proportion of coliform and TPC contamination in the RTU compared to both homebrew and commercial powder formula $(\mathrm{P}<0.05)$.

Table 3 Proportion of microbial contamination of different enteral preparation

\begin{tabular}{|cccc}
\hline Coliform & \multicolumn{2}{c}{ Ready-to-Use } & $\begin{array}{c}\text { p-value } \\
\text { (McNemar) }\end{array}$ \\
\cline { 2 - 3 } & Not contaminated & Contaminated & \\
\hline Homebrew & 6 & 0 & $<\mathbf{0 . 0 0 1}$ \\
\hline Not contaminated & 13 & 2 & \\
\hline Contaminated & & & $\mathbf{0 . 0 2 1}$ \\
\hline Commercial & 10 & 1 & \\
\hline Not contaminated & 9 & 1 & \\
\hline Contaminated & & & \\
\hline
\end{tabular}

\section{TPC}

\begin{tabular}{cc} 
Ready-to-Use & p-value \\
\hline Not contaminated & Contaminated
\end{tabular}

Homebrew

$\begin{array}{lcc}\text { Not contaminated } & 2 & 0 \\ \text { Contaminated } & 17 & 2\end{array}$

$0 \quad<\mathbf{0 . 0 0 1}$

2

Commercial

Not contaminated

Contaminated
0 2 


\section{Discussion}

Energy and macronutrient level accuracy of all preparations showed high degree in variation. In terms of macronutrient, homebrew formula has the highest deviation among all macronutrients. Compared to the study done by Mokhalalati, ${ }^{6}$ this study showed that homebrew had the highest degree of variability in nutrient content and physical properties compared to commercial enteral formula. The average of variability ranged from $16-50 \%$, while the commercial enteral formula was $4-7 \%$.

The microbial contamination analysis showed that there was no formula contaminated by Staphylococcus aureus. However, this was not the case for TPC and coliform contamination. Among all the formula, ready-to-use had the least proportion of microbial contamination. Contamination through equipments and utensils of homebrew enteral formula were already reported by several publications. ${ }^{4,6,7}$ This shows that the closed-system in preparation will limit microbial contamination.

Furthermore, the deviation of macronutrient value accuracy and microbial status found in this study has clinical and nutritional implication for malnourished patients and patients at risk of malnutrition. Although we used limited numbers of sample size in this study, it could be concluded that homebrew is inferior compared to commercial and RTU products, especially in energy and macronutrients accuracy, and microbial contamination status. Thus, it is recommended to use the ready-to-use or commercial formula for tube feeding in order to get accurate nutritional foods with low contaminant.

\section{Conflict of Interest}

Authors declared no conflict of interest regarding this study.

\section{Open Access}

This article is distributed under the terms of the Creative Commons Attribution 4.0 International License (http://creativecommons.org/licenses/by/4.0/), which permits unrestricted use, distribution, and reproduction in any medium, provided you give appropriate credit to the original author(s) and the source, provide a link to the Creative Commons license, and indicate if changes were made.

\section{References}

1. Burgos R, Sarto B, Elío I, Planas M, Forga M, Cantón A, et al. Prevalence of malnutrition and its etiological factors in hospitals. Nutr Hosp 2012;27(2):469. [Google Scholar]

2. Viganó P, Silva N, Cremonezi C, Vannucchi G, and Campanelli $\mathrm{M}$. Variation in the energy and macronutrient contents of the texture modified hospital diets. Rev Chil Nutr 2011;38(4):451. [Google Scholar]

3. Bankhead R, Boullata J, Brantley S, Corkins M, Guenter P, Krenitsky J, et al. Enteral nutrition practice recommendations. JPEN 2009;33(2):122. [Google Scholar]

4. Jalali M, Sabzghabaee AM, Badri SS, Soltani HA, Maracy MR. Bacterial contamination of hospital-prepared enteral tube feeding formulas in Isfahan, Iran. JRMS 2009;14(3):149. [Google Scholar]

5. BPOM RI. Peraturan Kepala Badan Pengawas Obat dan Makanan RI No HK.00.06.1.52.4011 tentang Penetapan Batas Maksimum Cemaran Mikroba dan Kimia dalam Makanan.

6. Carvalho MLR, Morais TB, Amaral DF, Sigulem DM. Hazard analysis and critical control point system approach in the evaluation of environmental and procedural sources of contamination of enteral feedings in three hospitals. JPEN 2000;24:296. [Google Scholar]

7. Sullivan MM, Sorreda-Esguerra P, Platon MB, Castro CG, Chou NR, Shott S, et al. Nutritional analysis of blenderized enteral diets in the Philippines. Asia Pac J Clin Nutr 2004;13(4):385. [Google Scholar] 